\title{
OPTIMIZATION OF PHYSICAL TRAINING OF STUDENTS OF HIGH SCHOOL WITH REGARD TO QUANTITATIVE FEATURES MUSCULAR COMPONENTS OF THEIR BODIES
}

\author{
Kolokoltsev M.M. ${ }^{1}$, Cieslicka Miroslawa ${ }^{2}$, Muszkieta Radoslaw ${ }^{2}$ \\ National Research Irkutsk State Technical University, Russia ${ }^{1}$ \\ Kazimierz Wielki University in Bydgoszcz, Poland ${ }^{2}$
}

\begin{abstract}
Annotation. Purpose: to provide a quantitative description of the muscle component of students ${ }^{\text {ee }}$ body with regard to their motor characteristics to improve training in the discipline "Physical Education". Material: a study of muscular component of the body in 1937 students aged 17-20 years old of age living in the Baikal region. Motor quality students were evaluated by tests. Problem analysis was conducted based on the data of Polish authors. Results: the dependence of the amount of content in muscle mass in the body of the frequency of physical training in high school. Also found significantly higher levels of performance in motor tests in the group of students with a high level of expression of muscle mass. Conclusions: the studies have shown a direct relationship content of lean body mass of locomotor activity. Set better indicator values in tests of physical fitness with a high content of muscle tissue. Lack of exercise training on older years is recommended to compensate for self-manage motor activities.
\end{abstract}

Keywords: students, muscle mass, physical, preparedness, physical culture.

\section{Introduction}

Among environmental factors, which influence on formation of bodyes componential composition, practicing of physical culture and sports are rather important. In this connection significance of studying of body"s componential composition, considering motion characteristics in complex studying of organism, is scientifically grounded and demanded [8].

It has been proved that componential composition of body reflects level of physical condition. At the same time it is a criterion of health and motion functioning $[2,5]$.

Thus, modern ideas, theories and methodic of physical education and medicine are single in opinion that it is necessary to consider individual specificities of person's development and condition [1, 11, 13, 15, 20]. Seeking of methods of physical load's individualization has been carrying out for long time, but mainly on the base of personification of methodic, pointed at achievement of mean-statistical standards of motion functioning. However, such approach weakens individual abilities of a person, because it requires their uniformity [10]. In opinion of V.V. Zaytseva [4], it is possible to significantly increase effectiveness of trainings and strengthen motivation for practicing of physical culture and sports with the help of methods and means, pointed at achievement of individual standards by every person on the base of his (her) constitutional-typological belonging. With it, level of indicators of body composition and their dynamic completely depends on structure of trainings, scope and intensity of physical loads [5, 14, 16-19].

Recent years, in Irkutskaya region there have been conducting researches on evaluation and analysis of only type-morphological status of 17-20 years old girls [6]. That is why it is important to fulfill additional researches for determination of composition and characteristic of interconnection between indicators of physical fitness and quantity of muscular component in girl students ${ }^{\text {ec }}$ bodies (girl student of technical HEE in Baykal district).

Purpose, tasks of the work, material and methods

The purpose of the research is to provide quantitative characteristics of girl studentse muscular component, (Baykal district) considering their motion abilities, for perfection of "Physical culture" lessons.

The methods and organization of the research. We have examinedMетоды и организация исследования. 1937 girl students of National research Irkutsk state technical university. Mean age of the girls was 18.5 years and varied from 17 to 20 years. In our work we used standard anthropometrical methodic of V.V. Bunak (1941), considering requirements of anthropological scientific research institute of MSU (1982), and with the help of standard devices. Our measurements were carried out in medical office of HEE, considering volunteer character of participation, considering rights and freedom of a personality, guaranteed by $\mathrm{Cl} .21$ and 22 of Constitution of RF. The research was fulfilled in compliance with principles of Helsinki Declaration (2008). All tested were informed about character and purposes of the research and gave written permission for participation in it.

From all, mentioned in literature methodic of determination of body“s component composition we chose and used methodic of R.N. Dorokhov and V.G. Petrukhin (1989) [3], which was tested in clinical and pedagogic practice. This scheme is highly informative and has significant advantages in comparison with subjective schemes of diagnostic; besides, it is the most convenient for application in evaluation of morphological characteristics. Componential level of variation of properties (CLP) was determined by content of fat (FM), muscular (MM) and bone (BM) masses. Evaluation of MM was fulfilled by summing of four circumferences (shoulder and hip (upper and lower) and by deduction of FM, multiplied by 3.13 from this sum:

$$
\mathrm{MM}=(\mathrm{CUS}+\mathrm{CLS}+\mathrm{CUH}+\mathrm{CLH})-\mathrm{FM} \times 3.14
$$

\footnotetext{
(c) Kolokoltsev M.M., Cieslicka Miroslawa, Muszkieta Radoslaw, 2015

http://dx.doi.org/10.15561/20755279.2015.0103
} 
Content of body's muscular component (in \%) was divided by 5 sigma classes: $\mathrm{M} \pm 0.67 \mathrm{~s}-\langle$ mean»value of indicators for sample. If they are in interval from $\pm 0.67 \mathrm{~s}$ to $\pm 1.34 \mathrm{~s}$; content of muscular mass was evaluated as "above middle" or "below middle". If it was in interval from $\pm 0.67 \mathrm{~s}$ to $\pm 1.34 \mathrm{~s}$, content was characterized as "above middle" or "below middle"[7]. If the data are out of limits $\pm 1.34 \mathrm{~s}$, muscular component was evaluated as "high" or "low".

First and second year girl students attended physical culture lessons twice a week; third and forth year girl students - once a week. Every lesson lasted for 90 minutes; the training were conducted in compliance with governmental educational standards of second generation (approximate academic program for higher educational establishments in "physical culture" discipline, 2000), mainly with using of fitness-aerobics system, oriented on education of all main motion abilities.

Motion abilities were evaluated by tests, worked out in scientific-research institute of physical culture of RF. For evaluation of quickness we used 20 meters run from walking (sec); speed endurance and dexterity - shuttle run 10 times by 5 meters (sec.); strength and power endurance of upper girdle muscles - hanging (sec.); speed-power endurance of muscular, bending torso - torso raising (times); flexibility - torso bending (cm); dynamic power of lower limbs ${ }^{\text {ee }}$ muscles - long jump from the spot (cm); endurance - 5 minutes run (meters).

We calculated mean arithmetic value of indicators, $M$, mean square deviation, $s$, and standard error $m$. According to recommendations of O.Yu. Rebrova [9], we used in our work parametric methods of material's processing, considering normal Gauss distribution of the studied quantitative characteristics. Evaluation of differences ${ }^{\text {ce }}$ confidence of independent samplese mean values was fulfilled with the help of $t$-criterion of Student. Differences between indicators with level $\mathrm{P}<0.05$ was considered as statistically significant. Calculation of indicators was conducted with the help of applied programs Statistica 6.0. For optimization of primary digital material's analysis we developed authors "e program complex "Analysis of data of population's physical health" (state registration of program for computers, №2010612275, dt. 26.03.2010).

\section{Results of the research}

It was determined that muscular mass (MM) of girls from Baykal district (17-20 years old age) in average was $23.7 \pm 0.08 \mathrm{~kg}$ that was $42.4 \pm 0.1 \%$ of body mass (in the range from 25.7 to $59.4 \%$ ), and expressiveness of MM $0.49 \pm 0.002$ (in the range from 0.18 to 0.68 ). Dispersion of girls ${ }^{e e} \mathrm{MM}$ indicator was from minimal value $14.5 \mathrm{~kg}$ to maximal $-44.9 \mathrm{~kg}$.

Studying of quantitative MM content in componential composition of girls ${ }^{e e}$ bodies during four years of their study at physical culture department witnesses, that the highest content of muscular tissue was in groups of first and second year girl students, when trainings practiced twice a week. Absolute content of MM in girls ,, bodies in this period was in average $24.8 \pm 0.1 \mathrm{~kg}(44.6 \%)$. When trainings started to be practiced once a week $\left(3^{\text {rd }}-4^{\text {th }}\right.$ years $)$ there was reduction of MM content characteristics up to $23.3 \pm 0.2 \mathrm{~kg}(40.2 \%)$ and. against this background, increase of fat mass (P $<0.05)$.

It is interesting to analyze dependence of motion tests ${ }^{\text {ee }}$ results on quantitative MM content (see table). For example in speed endurance and dexterity test (shuttle run $10 \times 5$ ) the best time $20.5 \pm 0.1$ sec. was shown by girls with high level of MM content $(\mathrm{P}<0.05)$. In other levels no dependence were found. In test for quickness $(20$ meter run from walking) we registered the same dependence of indicator ${ }^{e}$ s dynamic. The best result ( $3.78 \pm 0.1 \mathrm{sec}$.) was shown by girls with high $\mathrm{MM}$ content and the lowest result $(4.03 \pm 0.1 \mathrm{sec}$.) was shown by girls with $\mathrm{MM}$ expressiveness of "below middle" (P<0.05).

Dynamic of dependence of motion tests' results on level of muscular mass's expressiveness and anthropometrical parameters of girls (17-20 years old age)

\begin{tabular}{|c|c|c|c|c|c|}
\hline \multirow{3}{*}{$\begin{array}{l}\text { Anthropometrical } \\
\text { parameters and } \\
\text { motion tests }\end{array}$} & \multicolumn{5}{|c|}{ Content of muscular mass ( $\%$ from body mass) } \\
\hline & $\begin{array}{l}\text { Low (less } \\
\text { than }-1.34 \mathrm{~s})\end{array}$ & $\begin{array}{c}\text { Below middle } \\
\text { (from }-0.67 \mathrm{~s} \text { to } \\
-1.34 \mathrm{~s} \text { ) }\end{array}$ & $\begin{array}{l}\text { Middle } \\
\mathrm{M} \pm 0,67 \mathrm{~s}\end{array}$ & $\begin{array}{l}\text { Above middle } \\
\text { (from }+0.67 \mathrm{~s} \text { to } \\
+1.34 \mathrm{~s} \text { ) }\end{array}$ & $\begin{array}{c}\text { High (more than } \\
+1.34 \mathrm{~s})\end{array}$ \\
\hline & \multicolumn{5}{|c|}{ Values of indicators and tests } \\
\hline Body length, cm & $165.8 \pm 0.4$ & $165.4 \pm 0.3$ & $164.9 \pm 0.1$ & $165.0 \pm 0.3$ & $166.1 \pm 0.4$ \\
\hline Body mass, kg & $56.9 \pm 0.6$ & $54.9 \pm 0.3$ & $55.8 \pm 0.1$ & $56.09 \pm 0.4$ & $56.6 \pm 0.6$ \\
\hline $\begin{array}{l}\text { Chest } \\
\text { circumference, } \mathrm{cm}\end{array}$ & $78.7 \pm 0.1$ & $82.4 \pm 0.04$ & $86.1 \pm 0.05$ & $90.7 \pm 0.05$ & $90.6 \pm 0.4$ \\
\hline $\begin{array}{l}\text { Shuttle run } 10 \times 5 \mathrm{~m} \text {, } \\
\text { sec. }\end{array}$ & $21.3 \pm 0.1$ & $21.3 \pm 0.1$ & $21.2 \pm 0.06$ & $21.1 \pm 0.1$ & $20.5 \pm 0.1$ \\
\hline $\begin{array}{l}\text { Run from walking } \\
20 \mathrm{~m} \text {, sec. }\end{array}$ & $3.97 \pm 0.04$ & $4.03 \pm 0.1$ & $3.97 \pm 0.04$ & $3.98 \pm 0.1$ & $3.78 \pm 0.1$ \\
\hline
\end{tabular}




\begin{tabular}{|c|c|c|c|c|c|}
\hline \multirow{3}{*}{$\begin{array}{c}\text { Anthropometrical } \\
\text { parameters and } \\
\text { motion tests }\end{array}$} & \multicolumn{5}{|c|}{ Content of muscular mass (\% from body mass) } \\
\hline & $\begin{array}{l}\text { Low (less } \\
\text { than }-1.34 \mathrm{~s})\end{array}$ & $\begin{array}{c}\text { Below middle } \\
\text { (from }-0.67 \mathrm{~s} \text { to } \\
-1.34 \mathrm{~s} \text { ) }\end{array}$ & $\begin{array}{c}\text { Middle } \\
\mathrm{M} \pm 0,67 \mathrm{~s}\end{array}$ & $\begin{array}{l}\text { Above middle } \\
\text { (from }+0.67 \mathrm{~s} \text { to } \\
+1.34 \mathrm{~s})\end{array}$ & $\begin{array}{l}\text { High (more than } \\
+1.34 \mathrm{~s})\end{array}$ \\
\hline & \multicolumn{5}{|c|}{ Values of indicators and tests } \\
\hline $\begin{array}{l}5 \text { minutes run, } \\
\text { meters }\end{array}$ & $837.8 \pm 20.5$ & $880.2 \pm 5.9$ & $914.2 \pm 11.9$ & $918.0 \pm 11.1$ & $918.7 \pm 14.0$ \\
\hline Hanging, sec. & $8.8 \pm 0.3$ & $9.6 \pm 0.3$ & $9.7 \pm 0.1$ & $10.3 \pm 0.3$ & $11.3 \pm 0.6$ \\
\hline $\begin{array}{l}\text { Torso raising during } \\
30 \mathrm{sec} ., \text { times }\end{array}$ & $22.7 \pm 0.5$ & $23.2 \pm 0.4$ & $23.2 \pm 0.2$ & $23.8 \pm 0.6$ & $24.7 \pm 0.2$ \\
\hline Torso bending, $\mathrm{cm}$ & $8.9 \pm 0.1$ & $15.0 \pm 0,5$ & $14.9 \pm 0.2$ & $21.3 \pm 0.1$ & $28.2 \pm 0.2$ \\
\hline $\begin{array}{l}\text { Long jump from the } \\
\text { spot, cm }\end{array}$ & $119.9 \pm 0.5$ & $133.5 \pm 0.2$ & $151.2 \pm 0.2$ & $168.9 \pm 0.2$ & $183.3 \pm 0.5$ \\
\hline
\end{tabular}

Characteristic of general endurance (test 5 minutes run) witnesses that the best result was shown by girls with high and "above high" level of muscular mass content. With it, girls with such MM content run distance by 80.9 meter longer during 5 minutes than girls with "low" level $(\mathrm{P}<0.05)$.

In power tests (hanging and torso raising) we also registered that girls with high MM expressiveness showed better results.

Similar dynamic was registered during testing of sportsmen and not sportsmen in Lithuania [5], as well as persons, who trained weight lifting as a part of physical culture program at HEE [12].

Analysis of such characteristic as flexibility witnesses that in group of girls with high MM content indicators of "torso bending" was 3.2 times higher than in groups with low muscular mass $(28.2 \pm 0.2$ and $8.9 \pm 0.1 \mathrm{~cm})$ accordingly, $\mathrm{P}$ $<0.05)$.

In test for dynamic strength of lower limbs (long jump from the spot) girls with high MM content showed result by $52.8 \%$ higher than girl students with low MM level.

\section{Conclusions}

1. Quantity of muscular mass in componential composition of girls is higher in first two years of physical culture (with lessons being conducted twice a week) $(24.8 \pm 0.1 \mathrm{~kg})$. With passing to "once a week lessons" there happens reduction of $\mathrm{MM}$ content in girls ${ }^{\mathrm{se}}$ bodies by from $4.4 \%$ to $23.3 \pm 0.2 \mathrm{~kg} \%$ and increase of fat mass against this background ( $\mathrm{P}<$ $0.05)$.

2. In group of girls with high MM content results of all motion tests were better than in groups with "low" and "below middle" MM content.

3. Deficit of girl students ${ }^{\text {se }}$ motion functioning shall be compensated with controlled independent trainings.

\section{References:}

1. Bal'sevich V.K., Lubysheva L.I. [New technologies of formation of physical culture of the schoolchild]. Problemy sovershenstvovaniia fizicheskogo vospitaniia uchashchikhsia obshcheobrazovatel'nykh shkol. Mezhdunarodnyj seminar [Problems of improving physical education pupils of comprehensive schools. International workshop]. Moscow, 1993, pp. 42-50. (in Russian)

2. Bujkova O.M., Tristan V.G. Vliianie zaniatij razlichnymi vidami aerobiki na komponentnyj sostav tela studentok [Effect of different types of aerobic training on body composition component of students]. Vestnik IuzhnoUral'skogo gosudarstvennogo universiteta. 2010, vol.19, no.195, pp. 131-134. (in Russian)

3. Dorokhov R. N., Petrukhin V. G. Mediko-pedagogicheskie aspekty podgotovki iunykh sportsmenov [Medical and pedagogical aspects of training young athletes]. Smolensk, 1989, pp. 4-14. (in Russian)

4. Zajceva V.V. Metodologiia individual'nogo podkhoda $v$ ozdorovitel'noj fizicheskoj kul'ture na osnove sovremennykh informacionnykh tekhnologij. Dokt.dis. [Methodology individual approach in improving physical training on the basis of modern information technologies. Dokt. Diss.]. Moscow, 1995, 48 p. (in Russian)

5. Zuoziene I.J., Peculiarities of physical fitness and body composition of students engaged and not engaged in sports. Physical Education of Students, 2013, no.6, pp. 15-19. doi:10.6084/m9.figshare.840494

6. Kolokol'cev M.M., Lumpova O.M. Konstitucional'naia tipologiia organizma studentov Pribajkal'ia [Constitutional typology of students"e organism of Pribaikal region]. Vestnik Irkutskogo gosudarstvennogo tekhnicheskogo universiteta. 2013, no.7, pp. 267-273. (in Russian)

7. Nikolaev V.G. Metody ocenki individual'no-tipologicheskikh osobennostej fizicheskogo razvitiia cheloveka [Methods for assessing individual typological features of physical development of a man] Krasnoyarsk, KrasGMA Publ., 2005, 111 p. (in Russian) 
8. Nikolaev V.G., Sindeeva L.V. Opyt izucheniia formirovaniia morfofunkcional'nogo statusa naseleniia Vostochnoj Sibiri [The experience of studying the formation of morphofunctional status of Eastern Siberia population]. Saratovskij nauchno-medicinskij zhurnal. 2010, vol.6, no.2, pp. 238-241. (in Russian)

9. Rebrova O.Iu. Statisticheskij analiz medicinskikh dannykh. Primenenie paketa prikladnykh programm STATISTICA [Statistical analysis of medical data. Application software package STATISTICA]. Moscow, Mediasphere, 2002, 305 p. (in Russian)

10. Khodakovski-Mal'cevich L. Zavisimost' sportivnogo rezul'tata ot razvitiia fizicheskikh kachestv $i$ morfologicheskikh pokazatelej iunoshej na etapakh predvaritel'noj podgotovki k begu. Kand. dis. [The dependence of the sports results from the development of physical qualities and morphological parameters of boys during the preliminary preparation for the run. Cand. Diss.]. 1992, 18 p. (in Russian)

11. Khristovaia T.E. Vliianie fizicheskikh nagruzok na obmen veshchestv i gormonal'nyj status liudej $\mathrm{s}$ raznym somatotipom [The influence of physical activity on the metabolism and hormonal status of people with different somatotipom]. Fizicheskoe vospitanie studentov. 2011, no.6, pp. 131-135. (in Russian)

12. Chernozub A.A. Kharakter izmenenij pokazatelej sostava tela u studentov v processe zaniatij fizicheskoj kul'turoj $\mathrm{s}$ ispol'zovaniem kompleksov atletizma [The nature of changes in body composition of students in the physical training complexes with athleticism]. Fizicheskoe vospitanie studentov. 2011, no.3, pp. 99-102. (in Russian)

13. Gautier G., Thouvarecq R., Larue J. Influence of Experience on Postural Control: Effect of Expertise in Gymnastics. Journal of Motor Behavior. 2008, vol.40, no.5, pp. 400-408.

14. Kruk J. Intensity of lifetime physical activity and breast cancer risk among Polish women. Journal of Sports Sciences. 2009, vol.27, no.5, pp. 437-445.

15. McPherson J., Anderson B., Blown E., Kirkland J., McLachlan-Smith C. Non-individual approaches to understanding human development. Early Child Development and Care. 1990, vol.55, no.1, pp. 51-57.

16. Mota J., Silva P., Santos M.P., Ribeiro J.C., Oliveira J., Duarte J.A. Physical activity and school recess time: Differences between the sexes and the relationship between children's playground physical activity and habitual physical activity. Journal of Sports Sciences. 2005, vol.23, no.3, pp. 269-275.

17. Rhodes R.E., de Bruijn G-J. Automatic and Motivational Correlates of Physical Activity: Does Intensity Moderate the Relationship? Behavioral Medicine. 2010, vol.36, no.2, pp. 44-52.

18. Scott F., Rhodes R.E., Downs D.S. Does Physical Activity Intensity Moderate Social Cognition and Behavior Relationships? Journal of American College Health. 2009, vol.58, no.3,pp. 213-222.

19. Sobko I.N., Kozina Zh.L., Iermakov S.S., Muszkieta Radosław, Prusik Krzysztof, Cieślicka Mirosława, Stankiewicz Błaźej. Comparative characteristics of the physical and technical preparedness of the women's national team of Ukraine and Lithuania basketball (hearing impaired) before and after training to Deaflympic Games. Pedagogics, psychology, medical-biological problems of physical training and sports, 2014, no.10, pp. 45-51. http://dx.doi.org/10.5281/zenodo. 10490

20. Szalma J.L., Individual differences in human-technology interaction: incorporating variation in human characteristics into human factors and ergonomics research and design. Theoretical Issues in Ergonomics Science. 2009, no.10, pp. 381-397. http://dx.doi.org/10.1080/14639220902893613 


\section{Information about the authors:}

Kolokoltsev M.M.: http://orcid.org/0000-0001-6620-6296; mihkoll@ mail.ru; National Research Irkutsk State Technical University; Lermontova str., 84, Irkutsk, 664074, Russia.

Cieslicka Miroslawa: http://orcid.org/0000-0002-0407-2592; cudaki@ op.pl; Kazimierz Wielki University in Bydgoszcz; Chodkiewicza str. 30 , 85-064 Bydgoszcz, Poland

Muszkieta Radoslaw: http://orcid.org/0000-0001-6057-1583; radek@ muszkieta.com; Kazimierz Wielki University in Bydgoszcz; Chodkiewicza str. 30, 85-064 Bydgoszcz, Poland.

Cite this article as: Kolokoltsev MM Cieslicka Miroslawa, Muszkieta Radoslaw. Optimization of physical training of students of high school with regard to quantitative features muscular components of their bodies. Physical education of students, 2015, no.1, pp. 17-21. http://dx.doi.org/10.15561/20755279.2015.0103

The electronic version of this article is the complete one and can be found online at: http://www.sportpedu.org.ua/html/arhive-e.html

This is an Open Access article distributed under the terms of the Creative Commons Attribution License, which permits unrestricted use, distribution, and reproduction in any medium, provided the original work is properly cited (http:// creativecommons.org/licenses/by/3.0/deed.en).

Received: 27.11 .2014

Accepted: 27.12.2014; Published: 30.12.2014 